\title{
Molecular Characterization and Detection of African Oil Palm Ringspot Virus
}

\author{
Ivan Lozano $^{1}$, Francisco José Morales ${ }^{1}$, Ana Karine Martinez ${ }^{1}$ and Eduardo Amador Peña ${ }^{2}$ \\ 1Authors' addresses: ${ }^{1}$ Centro Internacional de Agricultura Tropical (CIAT), AA 6713, Cali, Colombia; \\ ${ }^{2}$ Corporación Colombiana de Investigación Agropecuaria (CORPOICA), El Mira, Tumaco, Nariño, Colombia \\ (correspondence to Ivan Lozano. E-mail: i.lozano@cgiar.org) \\ Received April 14, 2009; accepted May 13, 2009
}

Keywords: African oil palm, Elaeis guineensis, mancha anular, Flexiviridae, Colombia

\begin{abstract}
African oil palm ringspot virus (AOPRV) had been previously described as a fovea-like virus associated with a lethal disease of African oil palm (Elaeis guineensis) in South America. The original report was based on partial sequence and a distant relationship between AOPRV and Apple stem pitting virus, Apricot latent virus and Grapevine rupestris stem pitting-associated virus, definitive species of the genus Foveavirus, family Flexiviridae. We report the full sequence of the RNA genome of AOPRV, and demonstrate that this virus is more closely related to two unassigned virus species of the family Flexiviridae (Cherry green ring mottle virus and Cherry necrotic rusty mottle virus) than to any definitive species of the genus Foveavirus. Thus, AOPRV should be considered as a new species of the Flexiviridae until the International Committee on Taxonomy of Viruses (ICTV) resolves the taxonomic status of the increasing number of unassigned species in this family. The molecular characterization of AOPRV has provided a highly sensitive and reliable RT-PCR assay for the early detection of AOPRV in different genotypes of African, American (E. oleifera) and hybrid oil palms.
\end{abstract}

\section{Introduction}

The African oil palm (Elaeis guineensis) is an economically important agricultural commodity that provides $30 \%$ of all the vegetable oils consumed worldwide. The largest growers of African oil palm are Malaysia and Indonesia, but West Africa, the centre of origin of this plant species, is the second most important African oil palm-producing region, and has the highest per capita consumption of this vegetable oil in the world. Latin America is also an important producer of African oil palm and, to a lesser extent, of its native American oil palm (E. oleifera), used predominantly for crop improvement purposes. The renewed interest in alternative fuel sources, has led to a significant increase in the area planted to African oil palm in 2 tropical America (http://en.wikipedia.org/Oil_palm).
In Latin America, Colombia is the largest producer of African oil palm (170 000 ha), followed by Ecuador (130000 ha), Brazil (56 000 ha) and Costa Rica (52 000 ha). Peru used to be an important palm oil producer, but the ringspot disease caused the loss of thousands of oil palms after its emergence in 1969 (Dzido et al., 1978). The affected area, located in the north-western Amazon region of Peru, is now planted with illegal crops, mainly coca (Erythroxylum coca). The ringspot disease re-emerged in the mid-1970s in the main African oil palm-producing region of northwestern Ecuador, causing young palm losses between $40 \%$ and $95 \%$ (Dzido et al., 1978). The disease then spread north into south-western Colombia, one of the main African oil palm production zones (Tumaco, Nariño) in this country, causing palm losses between $45 \%$ and $100 \%$ in some plantations (Morales et al., 2002).

Investigations conducted since 2000 at the International Center for Tropical Agriculture (CIAT) in Palmira, Colombia, consistently show the presence of a filamentous virus (c. $800 \mathrm{~nm}$ long) associated with ringspot-affected palms in the municipality of Tumaco, Nariño, Colombia. Partial molecular sequence data obtained for African oil palm ringspot virus (AOPRV) showed that the filamentous virus was related to definitive and tentative species of the genus Foveavirus (Van Regenmortel et al., 2000; Morales et al., 2002).

The ringspot disease of oil palm is considered a major phytosanitary problem of this vegetable oil crop in south-western Colombia, where it still kills thousands of young palms every year. One of the main constraints to implementing effective disease control methods is the unknown nature of the dissemination mechanism of the pathogen. The known foveaviruses and similar flexiviruses are mainly pathogens of temperate fruit crops, transmitted by mechanical means during cultural operations, and do not have a known biological vector (Fauquet et al., 2005). However,

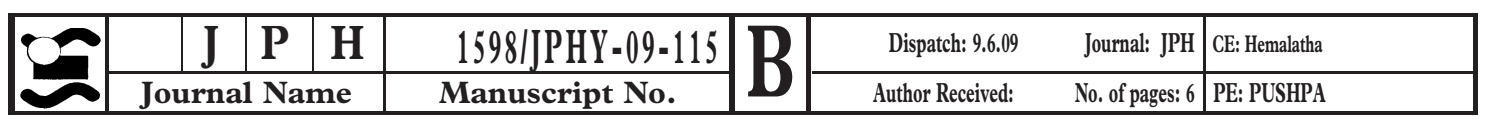


African oil palm does not require pruning in the early stages of development, when most diseased young palms become infected in the nursery. Another technical problem is the difficulty in detecting the virus by electron microscopy or serology due to its low titer in diseased oil palms, and the difficult nature of the plant as an experimental host. Originally, the presence of AOPRV was demonstrated by extraction of viral dsRNA from diseased oil palms (Morales et al., 2002), but the molecular characterization of the virus, described here, has allowed the implementation of a highly sensitive and reliable molecular diagnostic assay for detection of AOPRV.

\section{Materials and Methods}

Virus source, RNA extraction, cDNA synthesis and cloning

African oil palm ringspot virus was isolated from 1-year-old African oil palms affected by the ringspot disease under nursery conditions in the municipality of Tumaco, Nariño, south-western Colombia. The viral nucleic acid extraction procedure and cDNA synthesis were performed as described earlier (Morales et al., 2002). The dsRNA bands (Dodds and Bar-Joseph, 1993) were purified in low melting point 3 agarose gels (Gibco BRL, Invitrogen, USA) and extracted using a Rneasy Kit (Qiagen, Valencia, CA, USA). cDNAs clones were obtained from hydroxymethyl mercurate-denatured dsRNAs (Jelkmann et al., 1989) using oligo (dT)12-18; random primers (Promega, Madison, WI, USA); and the Super Script Choice System cDNA synthesis kit (Invitrogen, Carslbad, CA, USA). The cDNA was ligated into the SmaI site of pBlue-Script II (Stratagene, La Jolla, CA, USA). Sub-clones were generated by using different restriction enzymes possessing 6-bp recognition sites; followed by purification and cloning of the resulting restriction fragments. The 3 '-terminal 508 nucleotides (nt) of AOPRV were amplified using Rapid Amplification of cDNA Ends (3'-RACE), using a System kit (version E) according to supplier's instructions (Invitrogen). Total RNA was extracted from the spear leaf of AOPRV-infected oil palms using a RNeasy plant mini-kit (Qiagen, Hilden, Germany) and the sense, gene-specific primer $5^{\prime}$ TTATTAGCAGTCCCACCA-3' (position 7044-7062). The resulting PCR product was cloned into the pGEM-T easy vector (Promega).

\section{Sequencing and sequence analysis}

The cDNA clones obtained were sequenced by a combination of sub-cloning and internally primed sequencing, using a BigDye Terminator v1.1 Cycle Sequencing 4Kit (Applied Biosystems, CA, USA) and an AB1 373 automated Sequencer. Sequence data were analysed

5using SEQUenCHER version 4.1.2 for Macintosh. Comparative analyses, including multiple alignments of amino acid (aa) sequences and calculations of the genetic distances between sequences, were performed using NCBI BLASTX, and DNAMAN Version 4.13 (Lynnon Biosoft, Vaudreuil, QC, Canada).

\section{Viral RNA detection in diseased plants}

Spear leaves collected from a total of 99 one-year-old African and African-American (E. guineensis $\times$ E. oleifera hybrids) oil palms affected by the ringspot disease in the municipality of Tumaco, department of Nariño, Colombia, were assayed by reverse transcriptase PCR (RT-PCR) for the presence of AOPRV. PCR primers were designed to amplify a 875-bp region of the putative polymerase gene ( $R d R p)$ found in the open reading frame (ORF) 1 of AOPRV. RT-PCR assays were performed with total RNAs extracted from symptomatic leaves, using an SV Total RNA Isolation System (Promega). First-strand cDNA synthesis was performed using the forward primer FW165 5'-CCTTTGACTCTAGCCAAGA-3', and reverse primer Rev936 5'-GCAAATGAAACTCTTCCC-3'. PCR primers were used at $10 \mu \mathrm{M}$ and PCR parameters were: a preincubation at $94^{\circ} \mathrm{C} ; 2 \mathrm{~min}, 51^{\circ} \mathrm{C} ; 2 \mathrm{~min}, 72^{\circ} \mathrm{C}$; $2 \mathrm{~min}$, followed by 32 cycles of $94^{\circ} \mathrm{C} ; 1 \mathrm{~min}, 51^{\circ} \mathrm{C}$; $1 \mathrm{~min} 30 \mathrm{~s}$ and $72^{\circ} \mathrm{C} ; 1 \mathrm{~min}$, and extension final of $72^{\circ} \mathrm{C} ; 10 \mathrm{~min}$. PCR products were directly sequenced. Considering the occurrence of yet another lethal disease (bud rot) of oil palm, locally known as PC (Pudrición de Cogollo) in Tumaco, a total of eight young oil palms apparently affected by bud rot, were also tested by RT-PCR for the possible presence of AOPRV. Additionally, three hybrid palms obtained from the inter-specific cross of E. guineensis $\times$ E. oleifera, and maintained under unprotected field conditions, were also tested for the presence of AOPRV.

\section{Results}

Genome organization of African oil palm ringspot virus

Assembly of the overlapping AOPRV cDNA fragments obtained, revealed a genome of $7759 \mathrm{nt}$, polyadenylated at the 3'-terminus (accession number AY072921). Five potential ORFs were identified as shown in Fig. 1. The $5^{\prime}$-end non-coding region consists of $75 \mathrm{nt}$. The initiation codon $\mathrm{AUG}$ in ORF 1 is found at position 76. The next in-frame UAG stop codon is at position 5617, resulting in a polypeptide of 1847 aa with a calculated Mr 209 kDa. ORF 1 contains characteristic methyl-transferase, helicase and RNA-dependent RNA polymerase motifs (Koonin and Dolja, 1993) in the N- and C-terminal ends of a puta6 tive $209-\mathrm{kb}$ protein. The four constant residues present in all methyl-transferases, contained within distinct signature domains I, II and IV, are H 72, D128 and R131, and Y239 respectively (Rozanov et al., 1992). The highly conserved core NTP-binding motif of the putative RNA helicase GxxGxGKS was located at position 1041-1048. The conserved core RdRp motifs DxxxxD, TGxxxTxxxNT and GDD are also found in the C-terminal domain of the putative helicase motif (Poch et al., 1989) located at positions 1628-1635, 1681-1691 and 1714-1716 respectively.

Open reading frames 2-4 comprise the putative triple gene block (TGB) found only in fovea-, carla-, allexi-, mandari- and potexviruses of the family Flexiviridae. This is a conserved group of genes 


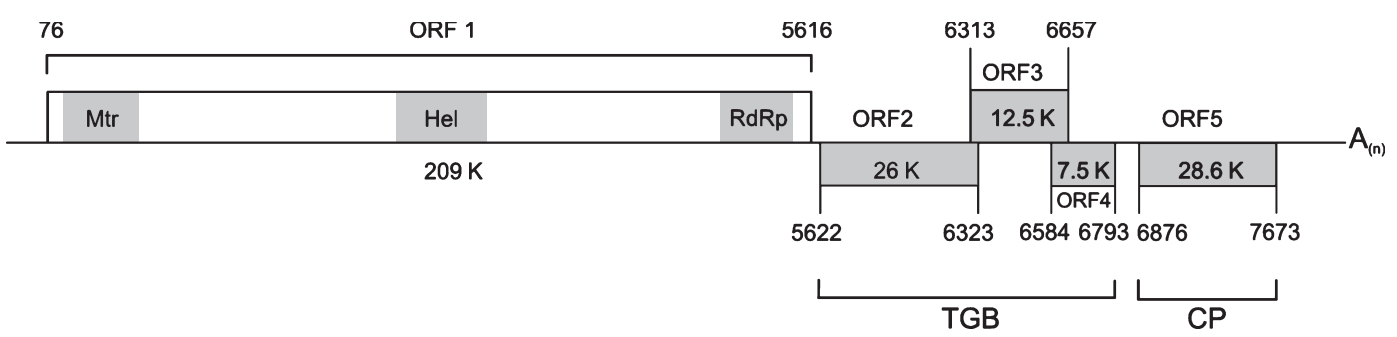

Fig. 1 Genome organization of AOPRV showing open reading frames (ORF 1-5) with the approximate sizes of their predicted polypeptides. The nucleotide position of the various ORFs is indicated numerically. Mtr, methyl-transferase; Hel, helicase; RdRp, RNA-dependent RNA polymerase; TGB, triple gene block; $\mathrm{CP}$, capsid protein

(NTP-binding protein, nucleic acid-binding protein and a membrane-binding protein) involved in cell-tocell transport of the virus in the plant (Mushegian and Koonin, 1993). ORF 2 (nt 5622-6323) has the potential to encode a polypeptide of 233 aa, with an estimated Mr 25 836. ORF 3 (nt 6313-6657) encodes a putative polypeptide of 114 aa, with an estimated $\mathrm{Mr}$ 12 560, and ORF 4 (nt 6584-6793) codes for a potential polypeptide of 69 aa with an estimated $\mathrm{Mr} 7492$. Finally, ORF 5 (nt 6876-7673) codes for the putative coat protein, a product of 265 aa with a calculated $\mathrm{Mr}$ 28 646. No internal nested ORFs were detected in the AOPRV genome.

\section{Taxonomic relationships}

Amino acid sequence identities of $46 \%, 42 \%, 40 \%$, $30 \%$ and $29 \%$ were observed between the $209-\mathrm{kDa}$ ORF 1 polypeptide of AOPRV and the corresponding translation products encoded by ORF 1 of Cherry green ring mottle virus (CGRMV), Cherry necrotic rusty mottle virus (CNRMV), Peach chlorotic mottle virus (PCMV), Sugarcane striate mosaic-associated virus (SCSMaV) and Banana mild mosaic virus (BanMMV) respectively (Table 1).

The putative RNA-dependent RNA polymerase domain (RdRp) of AOPRV and those of CGRMV, CNRMV and the banana flexiviruses [BanMMV and Banana virus $X(\mathrm{BVX})]$ share a $71 \%, 70 \%, 61 \%$ and $62 \%$ aa sequence identity, respectively, within the 300 C-terminal aa surrounding the GDD region (Table 1). Amino acid sequence identities were found (Table 1) between the TGBp1 of AOPRV and those of CNRMV (55\%), CGRMV (48\%), PCMV (39\%), Asian prunus virus-1 (APV-1) (36\%) and BanMMV (36\%). Amino acid sequence identities for TGBp2 were observed with the putative nucleic acid-binding proteins of BanMMV (41\%), BVX (41\%), the allexivirus Shallot virus $X$ $(40 \%)$ and CGRMV (39\%). TGBp3 shows aa sequence identity with the putative membrane protein of CGRMV (41\%), Potato virus $X(38 \%)$, APV-1

Table 1

Amino acid sequence identities (\%) between the putative proteins encoded by the open reading frames (ORF 1-5) of African oil palm ringspot virus and the corresponding proteins of selected, definitive (genera) and unassigned species of the family Flexiviridae

\begin{tabular}{|c|c|c|c|c|c|c|c|}
\hline Genera & Acronym & ORF1 (R-a p) & ORF1 (RdRp) & ORF2 (TGBp1) & ORF3 (TGBp2) & ORF4 (TGBp3) & ORF5 (CP) \\
\hline Allexivirus & ShVX & 14 & 33 & 19 & 40 & 28 & 24 \\
\hline Potexvirus & PVX & 15 & 35 & 24 & 37 & 38 & 37 \\
\hline Mandarivirus & ICRSV & 14 & 32 & 25 & 36 & 33 & 28 \\
\hline Carlavirus & PVM & 29 & 60 & 23 & 37 & 33 & 32 \\
\hline Foveavirus & ASPV & 30 & 63 & 32 & 32 & 30 & 32 \\
\hline Trichovirus & ACLSV & 25 & 47 & na & na & na & 15 \\
\hline Vitivirus & GVA & 19 & 46 & na & na & na & 19 \\
\hline Capillovirus & ASGV & 19 & 19 & na & na & na & 16 \\
\hline \multirow[t]{7}{*}{ Unassigned } & CGRMV & 46 & 71 & 48 & 39 & 41 & 45 \\
\hline & CNRMV & 42 & 70 & 55 & 37 & 35 & 42 \\
\hline & SCSMaV & 30 & 57 & 22 & 34 & 30 & 27 \\
\hline & BanMMV & 29 & 61 & 36 & 41 & 31 & 35 \\
\hline & BVX & $\mathrm{na}^{\mathrm{b}}$ & 62 & 22 & 41 & 25 & 32 \\
\hline & APV-1 & $\mathrm{na}^{\mathrm{b}}$ & 61 & 36 & 32 & 36 & 37 \\
\hline & PCMV & 40 & 64 & 39 & 32 & 31 & 34 \\
\hline
\end{tabular}

na, not applicable (no homologous protein available for comparison). na ${ }^{\mathrm{b}}$, not applicable (partial sequence). The selected flexiviruses and their GenBank accession numbers are: ShVX, Shallot virus X (M97264); PVX, Potato virus X (M95516); ICRSV, Indian citrus ringspot virus (AF406744); PMV, Potato virus M (D14449); ASPV, Apple stem pitting virus (D21829); ACLSV, Apple chlorotic leaf spot virus (M58152);

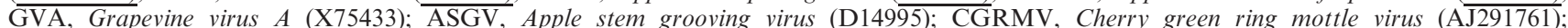
CNRMV, Cherry necrotic rusty mottle virus (AF237816.1); SCSMaV, Sugarcane striate mosaic-associated virus (AF315308); $\overline{\mathrm{BanMMV}}$, Banana mild mosaic virus (AF314662); BVX, Banana virus X (AY710267); APV-1, Asian prunus virus-1 (DQ205236); $\mathrm{PCMV,} \mathrm{Peach} \mathrm{chlorotic}$ mottle virus (NC-009892); R-a p, replication-associated proteins; RdRp, RNA-dependent RNA polymerase domain; TGBp1-3, triple gene block protein $1-3 ; \mathrm{CP}$, coat protein. 
(a)

$\stackrel{0.05}{.05}$

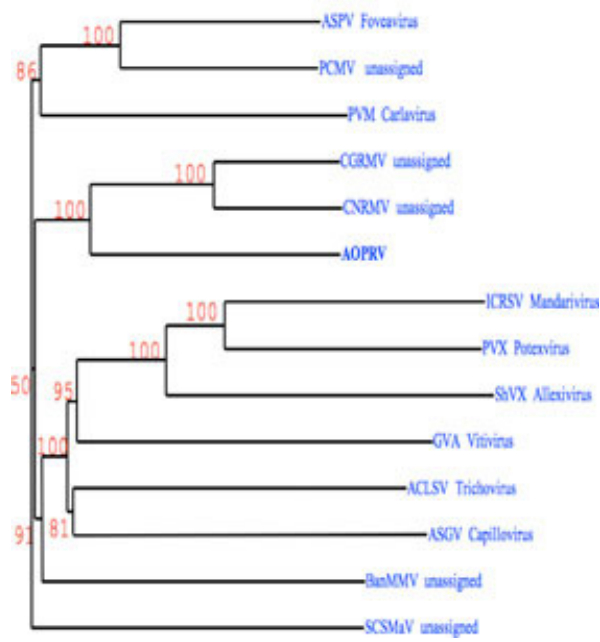

(c)
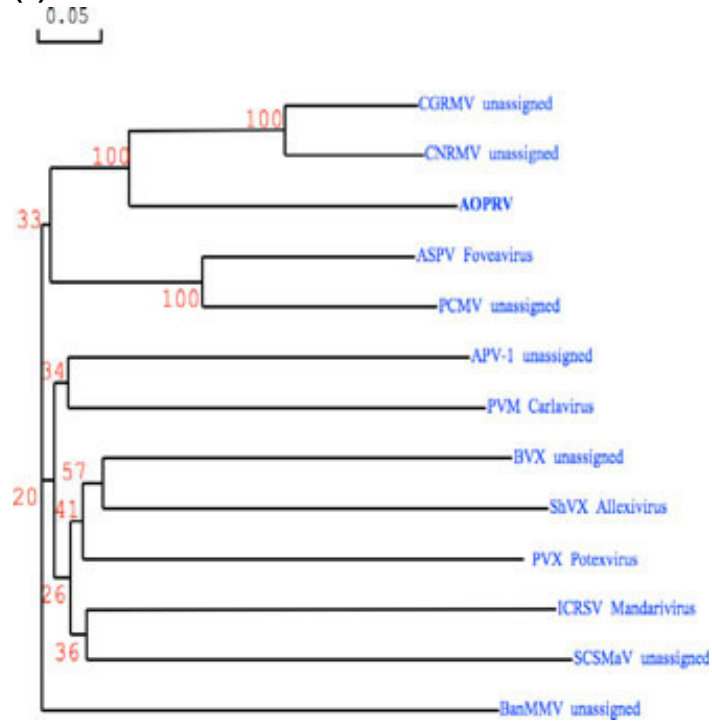

(b)

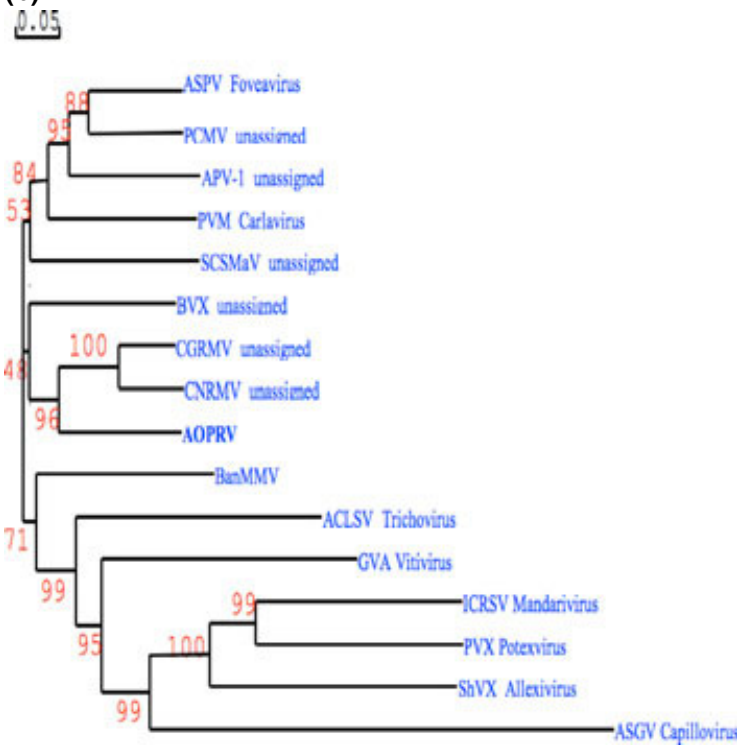

(d)

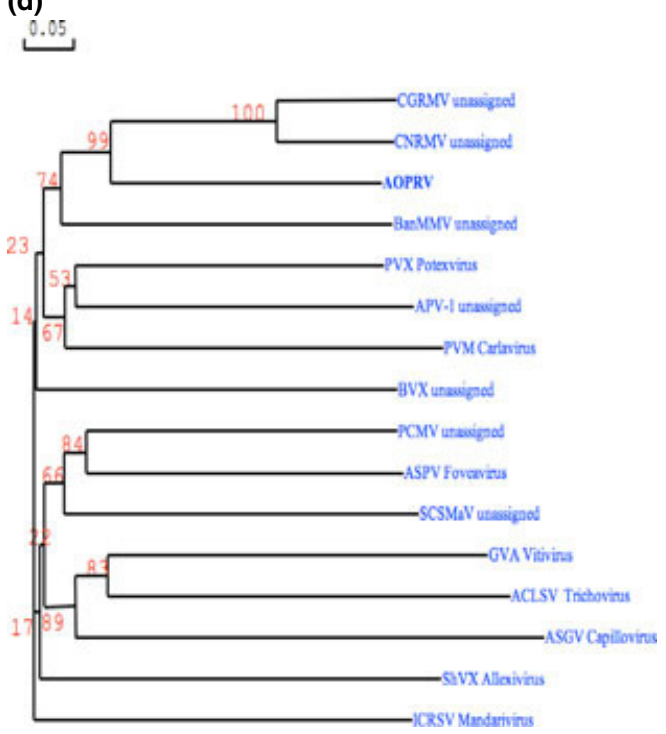

Fig. 2 Phylogenetic trees showing the position of African oil palm ringspot virus in relation to selected definitive virus species and genera of the family Flexiviridae, and unassigned viruses in this family, based on amino acid sequence identities between the proteins encoded by their 8,9 respective open reading frames (ORFs). Trees were constructed using DNAMAM (Lynon Bio/Scott). Values were obtained by boots trap analysis of 1000 replicates. (a) Replication-associated proteins; (b) RNA-dependent RNA polymerase; (c) TGBp1 and (d), coat protein

$(36 \%)$ and CNRMV (35\%). Finally, aa sequence identities of $45 \%, 42 \%, 37 \%$ and $37 \%$ were observed between the capsid protein of AOPRV and those of CGRMV, CNRMV, APV-1 and Potato virus $X$ respectively. The sequence KFAAFDFFDAVTSDCA, located at position 182 of this polypeptide, corresponds to a conserved core motif present in potex- and carlavirus coat proteins (Dolja et al., 1991).

Comparative phylogenetic analyses (Fig. 2a-d) consistently show that AOPRV is related to unassigned species of the family Flexiviridae, particularly CGRMV and CNRMV, and, to a lesser extent, BanMMV and BVX. AOPRV was only distantly related to definitive virus species in the Potexvirus and Allexivirus genera (Table 1). As shown in Fig. 2, the cluster of unassigned flexiviruses was also moderately related to the neighbour cluster containing the definitive (ASPV) and tentative (APV-1, SCSMaV and PCMV) species of the genus Foveavirus.

\section{Plant virus detection}

All of the 99 ringspot-affected young African oil palms assayed using RT-PCR, yielded the expected 875-bp fragment amplified by the AOPRV primers. Selected fragments obtained from these RT-PCR tests produced true sequences corresponding to AOPRV ORF1. The three hybrid oil palms assayed by RT-PCR in this investigation also yielded the expected 875-bp bands, demonstrating their susceptibility to AOPRV. On the contrary, none of the PC-affected young palms or the healthy control assayed, produced any visible PCR products (Fig. 3). 
Fig. 3 RT-PCR of individual African oil palms affected by the ringspot (samples $1-12$ ) or bud rot disease (13-20); $\mathrm{M}=1 \mathrm{~kb}$ ladder markers; $(+)$ positive and $(-)$ negative controls (AOPRVinfected and AOPRV-free plant tissue respectively)

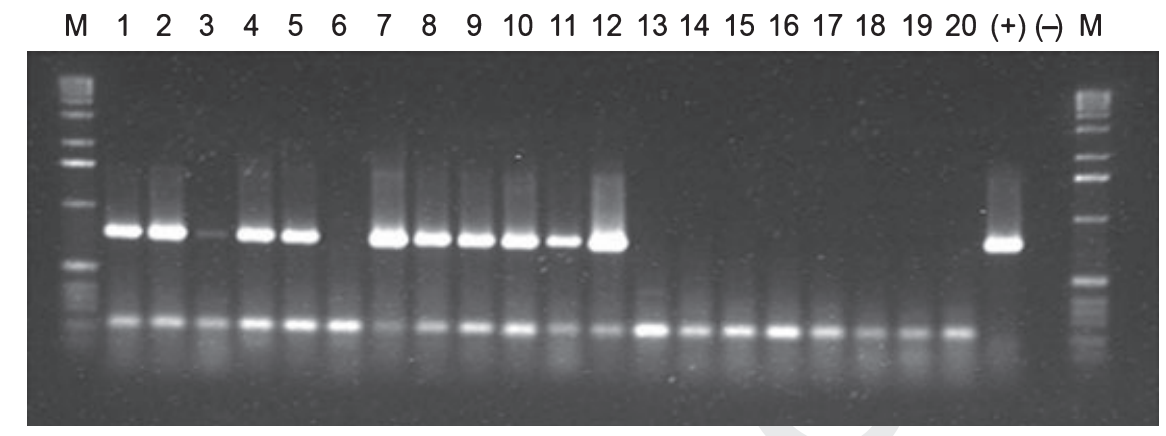

\section{Discussion}

When the genus Foveavirus was created in the late 1990s (Martelli and Jelkmann, 1998), it included Apple stem pitting virus and Grapevine rupestris stem pitting-associated virus as definitive species. These filamentous viruses possess five ORFs encoding: replication-related proteins (ORF1), the putative movement proteins (ORFs 2-4) or TGB, and the capsid protein (ORF5). In the seventh report of the International Committee on Taxonomy of Viruses (ICTV), CGRMV appears as a tentative foveavirus (Van Regenmortel et al., 2000). In the eighth report of the ICTV, Apricot latent virus was added to the list of accepted foveaviruses, but CGRMV was not considered anymore a tentative or accepted species of the genus Foveavirus. Rather, CGRMV, CNRMV, BanMMV, Citrus leaf blotch virus, Potato virus $T$ (PVT) and SCSMaV were included as 'unassigned' species in the family Flexiviridae (Fauquet et al., 2005). This family was created in 2004 to include species in eight different genera of filamentous RNA viruses, including the genus Foveavirus (Adams et al., 2004). Recently, BVX has been described as a new member of this family based on partial sequence data (Teycheney et al., 2005). A recent review (Martelli et al., 2007) includes the definitive genera Potexvirus, Mandarivirus, Allexivirus, Carlavirus, Foveavirus, Capillovirus, Vitivirus, Trichovirus; the putative genus Citrivirus; and the unassigned species BanMMV, CGRMV, CNRMV, PVT and SCSMaV, in the family Flexiviridae. AOPRV and Asian prunus virus-1 (APruV-1), -2 (APruV-2) and -3 (APruV-3) are mentioned in this review as additional putative members of the genus Foveavirus. However, the results presented in this investigation demonstrate that although AOPRV should be accepted as a member of the family Flexiviridae, it does not seem to be a species of the genus Foveavirus.

Within the family Flexiviridae, the presence of a TGB in AOPRV excludes the possibility of placing this virus in the genera Capillo-, Tricho-, Viti-, or Citrivirus, all of which lack a TGB. Additionally, AOPRV only has five ORFs, and most of the remaining genera of the Flexiviridae (i.e. Mandari-, Allexi- and Carlavirus) have six ORFs (Fauquet et al., 2005). The two remaining genera that possess five ORFs (Foveavirus and Potexvirus) are clearly not closely related to
AOPRV. In all past and present genomic analyses of AOPRV, the closest homologies have been observed with two unassigned flexiviruses: CGRMV and CNRMV, particularly at the polymerase, TGB and CP level. However, the genome organization of these viruses differs from that of AOPRV in that the cherry viruses have more than five ORFs. The other unassigned viruses in the Flexiviridae: APruV-1, -2 and -3, and PCMV seem to be closely related to the definitive species of the genus Foveavirus, although they form a separate cluster (Marais et al., 2006; James et al., 2007).

The molecular characterization of AOPRV made possible the implementation of a reliable virus detection assay in both African and hybrid progenies of African $\times$ American oil palms infected by AOPRV under natural conditions. The early diagnosis of AOPRV in the nursery stage is very important for a perennial crop, such as African oil palm, that has a very long productive life. African oil palm 'ringspot' is a lethal disease that generally affects young palms at the beginning of their productive life. A sensitive virus detection assay in the nursery stage prevents the transplant of young infected palms in the definitive plantation, where they usually express the lethal symptoms induced by AOPRV.

It has been demonstrated here that the causal agent of the African and American oil palm ringspot disease is a virus that belongs to the family Flexiviridae (Martelli et al., 2007). Although AOPRV is more closely related to viruses in the genus Foveavirus than to viruses in any other ICTV-approved genus in the Flexiviridae, it cannot be considered a foveavirus. The relatively close relationship that exists between AOPRV and the unassigned flexiviruses CGRMV and CNRMV is interesting, but probably not enough to expect these three viruses to constitute a new genus in the near future. Unlike foveaviruses and the two unassigned cherry viruses, AOPRV is a tropical virus that infects monocotyledonous plant species and, therefore, it is not surprising to observe significant differences between AOPRV and the temperate fruit crop flexiviruses. BanMMV and BVX are also tropical flexiviruses infecting a monocot, and may have followed a similar evolutionary path, as suggested by the partial relationships noticed in this investigation between these banana viruses and AOPRV. 
It is important to investigate the epidemiology of AOPRV, considering its fairly rapid dissemination in the affected regions of Peru, Ecuador and Colombia, and its socioeconomic importance. Although the possibility of mechanical transmission by contaminated tools, mainly machetes, cannot be ruled out in the case of AOPRV, the possible existence of a slow-moving but persistent vector, such as mites (vectors of allexiand trichoviruses) or mealybugs/scales (vectors of vitiviruses), is currently under investigation in our laboratory.

\section{References}

Adams MJ, Antonw JL, Bar-Joseph M, Brunt AA, Candresse T, Foster GD, Martelli GP, Milne RG, Fauquet CM. (2004) The new plant virus family Flexiviridae and assessment of molecular criteria for species demarcation. Arch Virol 149:1045-1060.

Dodds JA, Bar-Joseph M. (1993) Double-stranded RNA from plants infected with closteroviruses. Phytopathology 73:419-423.

Dolja VV, Boyko VP, Agranovski AA, Koonin EV. (1991) Filogeny of capsid proteins of rod-shaped and filamentous RNA plant viruses: two families with distinct patterns of sequence and probably structure conservation. Virology 184:79-86.

Dzido JL, Genty P, Ollagnier M. (1978) Les principales maladies du palmier à huile en Equateur. Oléagineuc 33:55-60.

Fauquet CM, Mayo MA, Maniloff J, Desselberger U, Ball LA. Virus Taxonomy: Eigth Report of The International Committee on Taxonomy of Viruses. London, Elsevier, Academic Press, 2005.

James D, Varga A, Croft H. (2007) Analysis of the complete genome of Peach chlorotic mottle virus: identification of non-AUG start codons, in vitro coat protein expression, and elucidation of serological cross-reactions. Arch Virol 152:2207-2215.
Jelkmann W, Martin RR, Maiss E. (1989) Cloning of four plant viruses for small quantities of double stranded RNA. Phytopathology 79:1250-1253.

Koonin EV, Dolja VV. (1993) Evolution and taxonomy of positivestrand RNA viruses: implication of comparative analysis of amino acid sequences. Crit Rev Biochem Mol Biol 28:375-430.

Marais A, Svanell-Dumas L, Foissac X, Gentit P, Candresse T. (2006) Asian prunus viruses: new related members of the family Flexiviridae in Prunus germplasm of Asian origin. Virus Res 120:176-183

Martelli GP, Jelkmann W. (1998) Foveavirus, a new plant virus genus. Arch Virol 143:1245-1249.

Martelli GP, Adams MJ, Kreuze JF, Dolja VV. (2007) Family Flexiviridae: a case study in virion and genome plasticity. Annu Rev Phytopathol 45:73-100

Morales FJ, Lozano I, Velasco AC, Arroyave JA. (2002) Detection of a fovea-like virus in African oil palms affected by a lethal 'ringspot' disease in South America. J Phytopathol 150:611-615.

Mushegian AR, Koonin EV. (1993) Cell-to-cell movement of plant viruses: insights from aminoacid sequence comparisons of movement proteins and from analogies with cellular transport systems. Arch Virol 133:239-257.

Poch O, Sauvaget I, Delarve M, Tordo N. (1989) Identification of four conserved motifs among the RNA-dependent polymerase encoding elements. EMBO J 8:3867-3874.

Rozanov MN, Koonin EV, Gorbalenya AE. (1992) Conservation of the putative methyl-transferase domain: a hallmark of the 'Sindbis-like' supergroup of positive-starnd RNA viruses. J Gen Virol 73:2129-2124.

Teycheney PV, Marais A, Svanella-Dumas L, Dulucq MJ, Candresse T. (2005) Molecular characterization of Banana virus X, a novel member of the Flexiviridae family. Arch Virol 150:1715-1727.

Van Regenmortel MHV, Fauquet CM, Bishop DHL et al. Virus Taxonomy: Seventh Report of the International Committee on Taxonomy of Viruses. New York, Academic Press, 2000. 


\section{Author Query Form}

\section{Journal: $\quad$ JPH}

Article: 1598/JPHY-09-115

Dear Author,

During the copy-editing of your paper, the following queries arose. Please respond to these by marking up your proofs with the necessary changes/additions. Please write your answers on the query sheet if there is insufficient space on the page proofs. Please write clearly and follow the conventions shown on the attached corrections sheet. If returning the proof by fax do not write too close to the paper's edge. Please remember that illegible mark-ups may delay publication.

Many thanks for your assistance.

\begin{tabular}{|c|c|c|}
\hline $\begin{array}{l}\text { Query } \\
\text { reference }\end{array}$ & Query & Remarks \\
\hline 1 & $\begin{array}{l}\text { AUTHOR: Please identify and encircle the forename and surname of all } \\
\text { authors. }\end{array}$ & \\
\hline 2 & $\begin{array}{l}\text { AUTHOR: Please check this website address and confirm that it is correct. } \\
\text { (Please note that it is the responsibility of the author(s) to ensure that all URLs } \\
\text { given in this article are correct and useable). }\end{array}$ & \\
\hline 3 & $\begin{array}{l}\text { AUTHOR: Please give manufacturer information for Gibco BRL, Invitrogen: } \\
\text { town and state. }\end{array}$ & \\
\hline 4 & AUTHOR: Please give address information of Applied Biosystems: Town. & \\
\hline 5 & $\begin{array}{l}\text { AUTHOR: Please give manufacturer information for sequencher version 4.1.2 } \\
\text { for Macintosh: company name, town, state (if USA), and country. }\end{array}$ & \\
\hline 6 & AUTHOR: Please check edit "a putative 209-kb protein". & \\
\hline 7 & AUTHOR: Please check the page range in Rozanov et al. (1992). & \\
\hline 8 & $\begin{array}{l}\text { AUTHOR: Please give manufacturer information for Lynon Bio/Scott: } \\
\text { company name, town, state (if USA), and country. }\end{array}$ & \\
\hline 9 & $\begin{array}{l}\text { AUTHOR: Figure } 2 \text { has been saved at a low resolution of } 322 \mathrm{dpi} \text {. Please } \\
\text { resupply at } 600 \text { dpi. Check required artwork specifications at http:// } \\
\text { www.blackwellpublishing.com/authors/digill.asp }\end{array}$ & \\
\hline
\end{tabular}




\section{USING E-ANNOTATION TOOLS FOR ELECTRONIC PROOF CORRECTION}

\section{Required Software}

Adobe Acrobat Professional or Acrobat Reader (version 7.0 or above) is required to e-annotate PDFs. Acrobat 8 Reader is a free download: http://www.adobe.com/products/acrobat/readstep2.html

Once you have Acrobat Reader 8 on your PC and open the proof, you will see the Commenting Toolbar (if it does not appear automatically go to Tools>Commenting>Commenting Toolbar). The Commenting Toolbar looks like this:

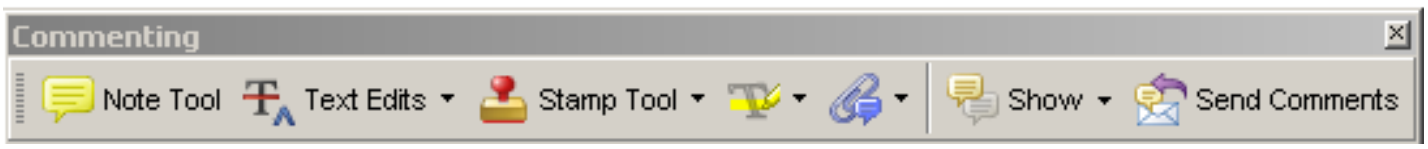

If you experience problems annotating files in Adobe Acrobat Reader 9 then you may need to change a preference setting in order to edit.

In the "Documents" category under "Edit - Preferences", please select the category 'Documents' and change the setting "PDF/A mode:" to "Never".

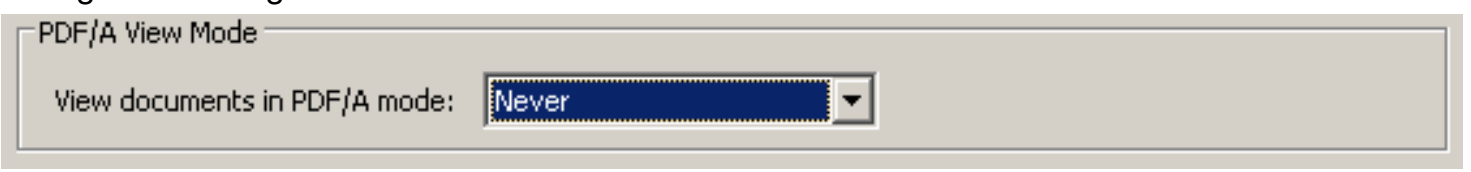

\section{Note Tool - For making notes at specific points in the text}

Marks a point on the paper where a note or question needs to be addressed.

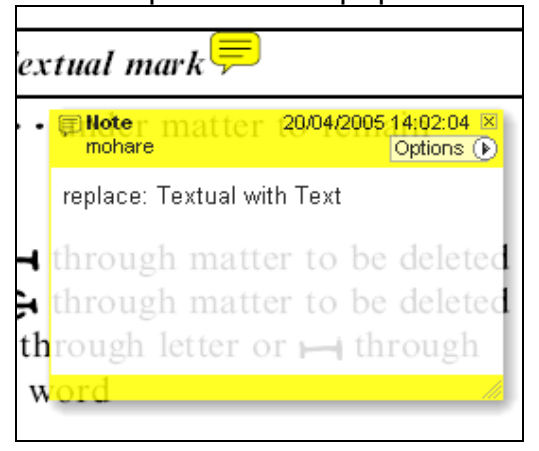

How to use it:

1. Right click into area of either inserted text or relevance to note

2. Select Add Note and a yellow speech bubble symbol and text box will appear

3. Type comment into the text box

4. Click the $X$ in the top right hand corner of the note box to close.

Replacement text tool - For deleting one word/section of text and replacing it

Strikes red line through text and opens up a replacement text box.

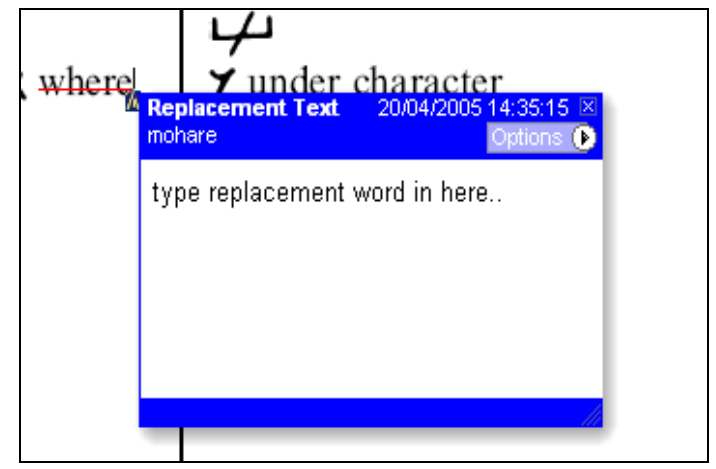

\section{How to use it:}

1. Select cursor from toolbar

2. Highlight word or sentence

3. Right click

4. Select Replace Text (Comment) option

5. Type replacement text in blue box

6. Click outside of the blue box to close

Cross out text tool - For deleting text when there is nothing to replace selection Strikes through text in a red line.

\begin{tabular}{|l|}
\hline substitute part of one or \\
more word(s) \\
Change to italies \\
Change to capitals \\
Change to small capitals \\
\hline
\end{tabular}
How to use it:
1. Select cursor from toolbar
2. Highlight word or sentence
3. Right click
4. Select Cross Out Text 


\section{(W)WILEY-BLACKWELL}

Approved tool - For approving a proof and that no corrections at all are required.

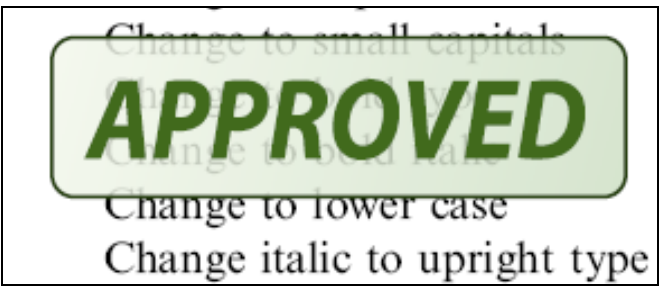

How to use it:

1. Click on the Stamp Tool in the toolbar

2. Select the Approved rubber stamp from the 'standard business' selection

3. Click on the text where you want to rubber stamp to appear (usually first page)

Highlight tool — For highlighting selection that should be changed to bold or italic. Highlights text in yellow and opens up a text box.

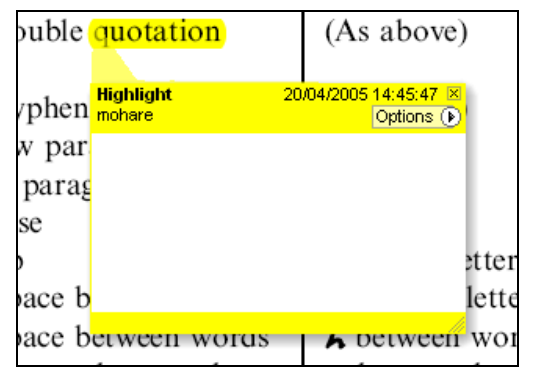

How to use it:

1. Select Highlighter Tool from the commenting toolbar

2. Highlight the desired text

3. Add a note detailing the required change

Attach File Tool - For inserting large amounts of text or replacement figures as a files. Inserts symbol and speech bubble where a file has been inserted.

\section{matter to be changed matter to matter to be changed matter to be changed} How to use it:

1. Click on paperclip icon in the commenting toolbar

2. Click where you want to insert the attachment

3. Select the saved file from your PC/network

4. Select appearance of icon (paperclip, graph, attachment or tag) and close

\section{Pencil tool - For circling parts of figures or making freeform marks}

Creates freeform shapes with a pencil tool. Particularly with graphics within the proof it may be useful to use the Drawing Markups toolbar. These tools allow you to draw circles, lines and comment on these marks.

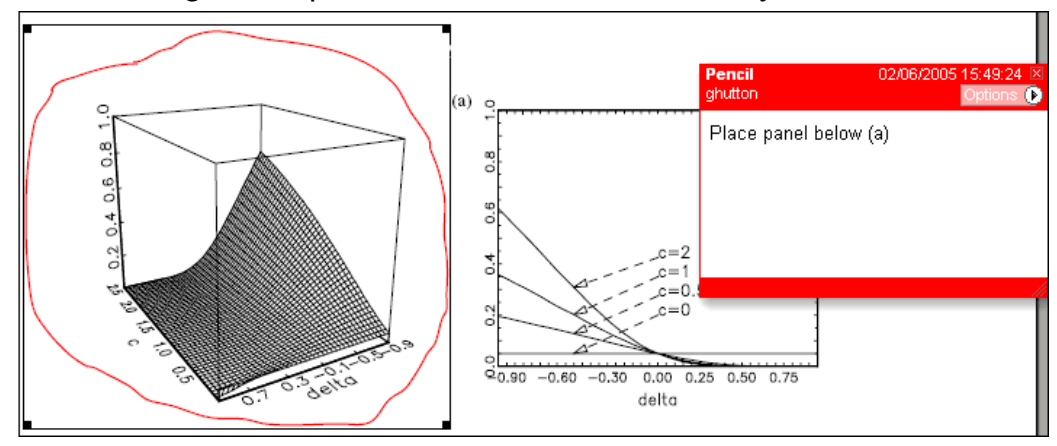

How to use it:

1. Select Tools $>$ Drawing Markups $>$ Pencil Tool

2. Draw with the cursor

3. Multiple pieces of pencil annotation can be grouped together

4. Once finished, move the cursor over the shape until an arrowhead appears and right click

5. Select Open Pop-Up Note and type in a details of required change

6. Click the $\mathrm{X}$ in the top right hand corner of the note box to close. 


\section{WILEY-BLACKWELL}

Help

For further information on how to annotate proofs click on the Help button to activate a list of instructions:

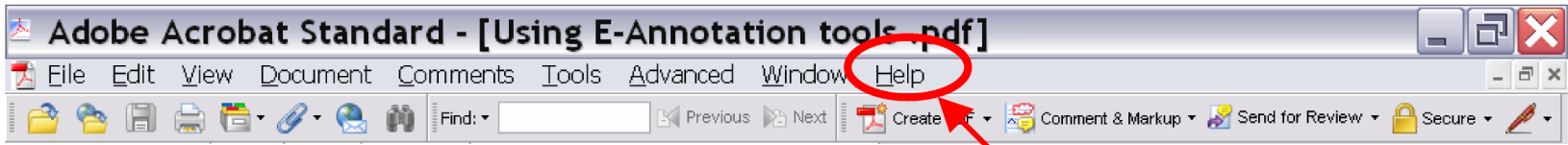

